\title{
The effect of zinc oxide based sealer on bone defects healing
}

\author{
Marija Nikolić, Jelena Popović, Jovanka Gašić, Radomir Barac \\ University of Nišs, Medical faculty, Department of Restorative dentistry and Endodontics, Clinic of Dentistry, Nišs, Serbia
}

\begin{abstract}
SUMMARY
Introduction Obturation as the final phase of endodontic treatment aims to provide complete hermetic filling along the entire length of the canal system from the coronal opening to the apical end. The aim of this study was to evaluate histological response of bone tissue on the implantaton of zinc oxide based material in artificially prepared defect in the mandible of rats. Material and method For the experiment, sixteen male Wistar rats were used. Using sterile steel burs a defect was made in mandible, between the midline and mental foramen. Zinc oxide based sealer was implanted in the defects of experimental group while the defects of control group healed spontaneously. One half of animals in both groups were sacrificed after thirty days, and the second half after ninety days. Microscopic preparations consisted of the defect with surrounding bone and after processing were analysed using light microscopy.

Results The thirtieth day after implantation of the material, fibrovascular connective tissue was noted, with scant chronic inflammatory cell infiltrate. Away from the experimentally made defect, in the depth of the bone, lamellar bone with well-formed larger osteons was noted as well as enlarged Volkmann and Haversian canals. Ninety days after implantation of the material, there was no restitutio ad integrum, but intense focal remodelling of bone tissue was noted.

Conclusion Endomethasone $\mathrm{N}$ slowed down bone tissue healing process by showing the signs of prolonged inflammation in bone tissue in which it has been implanted. Extension of the healing process is reflected in the slow replacement of fibrovascular connective tissue with newly formed bone tissue.

Keywords: sealers; obturation; bone healing
\end{abstract}

\section{INTRODUCTION}

The aim of obturation as the final phase of endodontic treatment is to provide complete hermetic filling along the entire length of the canal system from the coronal opening to the apical end. It should break communication between endodontic and periodontal tissues and thus prevent reinfection of periapical region [1]. Materials used for obturation should have a number of physical, chemical and biological properties and should not extend beyond the end of the canal system [1]. When a biomaterial comes in contact with the tissues and fluids of the human body there is always some form of interaction and therefore it is necessary for material to be biocompatible and harmless in the biological surrounding [2].

Overinstrumentation and consequently overfilling of the root canal significantly increase the risk of adverse impacts of filling material [3]. Overfilling causes inflammation and slows down wound healing $[4,5]$. The negative effect is usually more pronounced until the material fully sets and it is attributed to the components of the material [6]. Slow release of harmful agents over long periods of time depends on the solubility of materials and the degree of material exposure to tissue fluids [2].

Zinc oxide based sealers are most commonly used in the clinical practice as well as comparative sealers in studies that examine the effect of biomaterials $[4,7]$. The results of these studies, however, are not encouraging. According to some authors, certain materials from this group are highly toxic, and should not be used as sealers [7]. The toxicity is attributed mainly to the presence of eugenol or formaldehyde in some formulations of these materials $[8,9]$.

The aim of this study was to evaluate histological response of bone tissue on the implantation of zinc oxide based material in artificially prepared defects in the mandible of rats.

\section{MATERIALS AND METHOD}

For the experiment, 16 Wistar male rats were used, weight 160-180 g (approved by the Ethics Committeeof the Faculty of Medicine in Niš No. 01 3797). During the experimental procedure, animals were anaesthetized by intraperitoneal injection of ketamine hydrochloride $(0.1 \mathrm{ml}$ per $100 \mathrm{~g}$ of weight). After preparation procedure, between midline and mental foramen of the left mandible of all animals, a defect (diameter of $1.4 \mathrm{~mm}$ and $1.6 \mathrm{~mm}$ depth) was made using sterile stainless steel fissure burs.

Animals of the experimental group $(\mathrm{n}=12)$ were divided into the two subgroups:

- The first subgroup $(n=6)$ was sacrificed after 30 days;

- The second subgroup $(\mathrm{n}=6)$ was sacrificed after 90 days.

In bone defects of experimental group animals, ,Endomethasone N" (Septodont, France) prepared by the manu- 


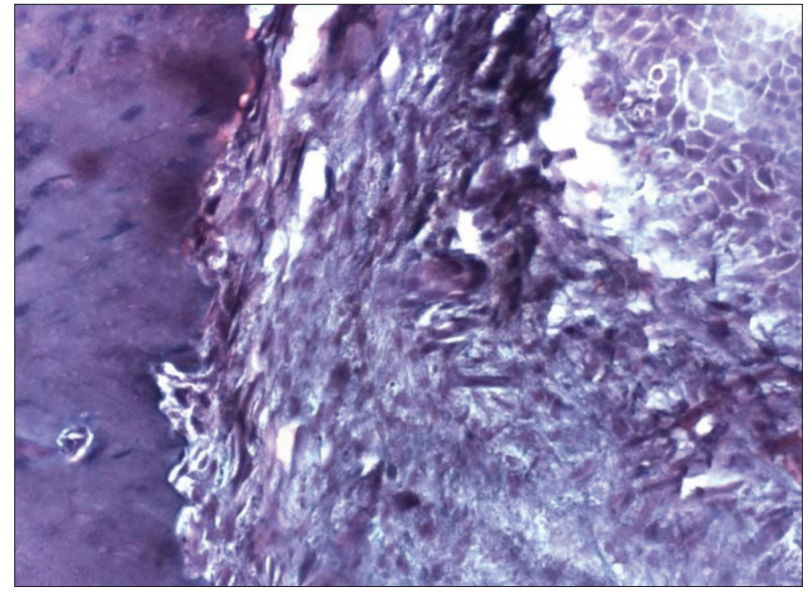

Figure 1. Histological finding of the defect 30 days after implantation of Endomethasone N. Fibrovascular connective tissue with scarce inflammatory cell infiltrate is visible. Surrounding bone is without osteon-type structure (HE, 800x).

Slika 1. Histološki nalaz defekta u kosti 30 dana nakon implantacije endometazona N. Fibrovaskularno vezivno tkivo sa oskudnim inflamatornim ćelijskim infiltratom. Okolna kost bez građe po tipu osteona (HE, 800x).

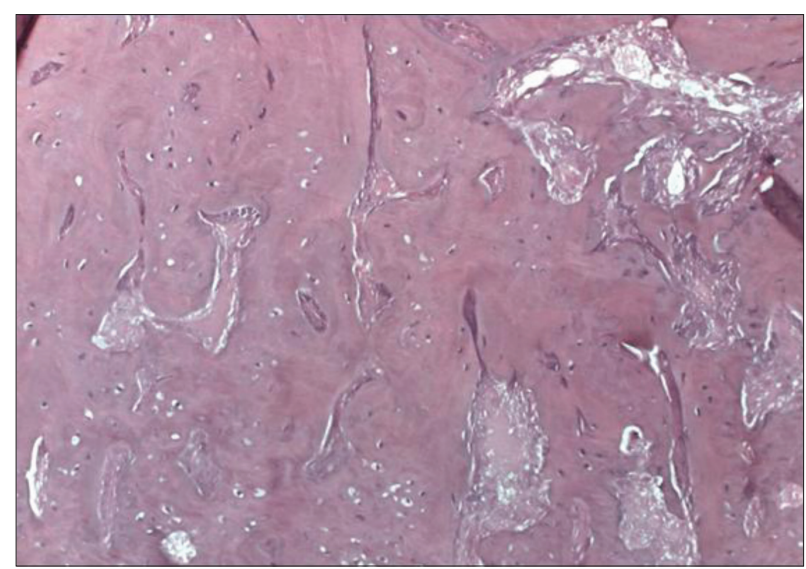

Figure 3. Histological finding of the defect 90 days after implantation of Endomethasone N. Newly formed bone with diffuse distribution of mature connective tissue is noted (HE, 400x).

Slika 3. Histološki nalaz defekta u kosti 90 dana nakon implantacije endometazona N. Novoformirana kost sa difuzno raspoređenim zrelim vezivnim tkivom (HE, 400x).

facturer's instructions was implanted. Bone defects in the control group $(n=4)$ were left to heal spontaneously without any implants. Two animals of the control group were sacrificed after thirty days and two animals after ninety days. After the estimated time the animals were sacrificed by an overdose of anaesthetic (ketamine hydrochloride). The tissue samples were made by resection of the mandible consisting of the defect and surrounding bone.

Tissue samples were fixed in 10\% buffered formalin, demineralized in $10 \%$ formic acid, dehydrated in a series of graded alcohols and embedded in paraffin wax. Cutting was performed in the buccolingual direction on the microtome with $2 \mu \mathrm{m}$ thick glass knives. The slides were stained with hematoxylin and eosin. Microscopic analysis was performed using light microscopy with digital camera Leica DFC 295.

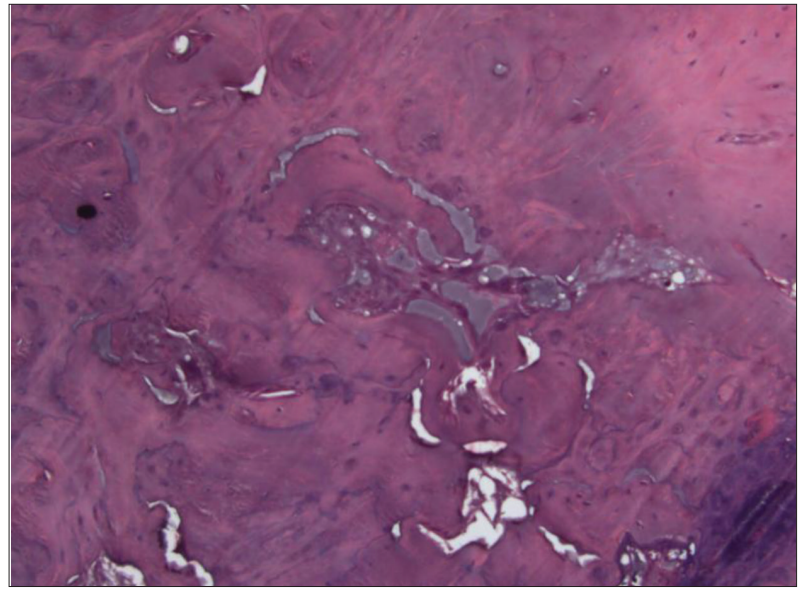

Figure 2. Histological finding of the defect 30 days after implantation of Endomethasone N. Thickening of cement lines and expansion of Volkmann and Haversian canals in the bone tissue away from the edges of the defect are visible (HE, 400x).

Slika 2. Histološki nalaz defekta u kosti 30 dana nakon implantacije endometazona N. Zadebljanje cementnih linija i proširenje Folkmanovih i Haversovih kanala u koštanom tkivu udaljenom od ivice defekta (HE, 400x).

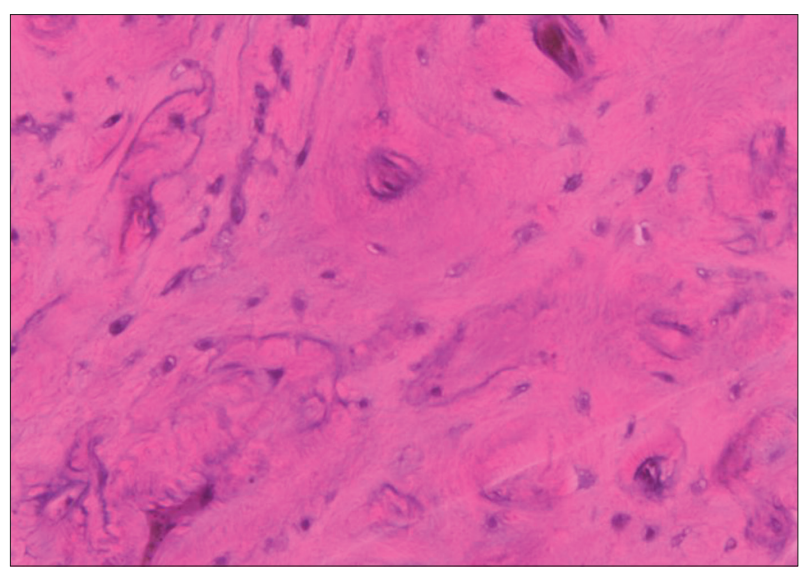

Figure 4. Histological finding of the defect 30 days after implantation of Endomethasone N. Bone shows normal micromorphology away from the defect (HE, 800x).

Slika 4. Histološki nalaz defekta u kosti 90 dana nakon implantacije endometazona N. Kost udaljena od defekta je normalne mikromorfologije (HE, 800x).

\section{RESULTS}

\section{Experimental group}

The thirtieth day after the implantation of material, fibrovascular connective tissue was noted, with scant focal chronic inflammatory cell infiltrate, while surrounding bone was hypocellular without the presence of Haversian system (in 5 out of 6 samples) (Figure 1). Small osteocytes with hyperhromatic nuclei were stored in slightly enlarged lacunae. Osteoblasts were few in number, while the presence of osteoclasts was inconspicuous. In areas of non-resorbed material, which was lost during processing of histopathological preparations, empty spaces were noticed. Away from experimentally made defect, in the depth of the bone, lamellar bone with well-formed larger osteons was noted as well as enlarged Volkmann and Haversian canals (Figure 2). Expanded interstitial lamellae were observed in osteons, osteocytes and lacunae were 


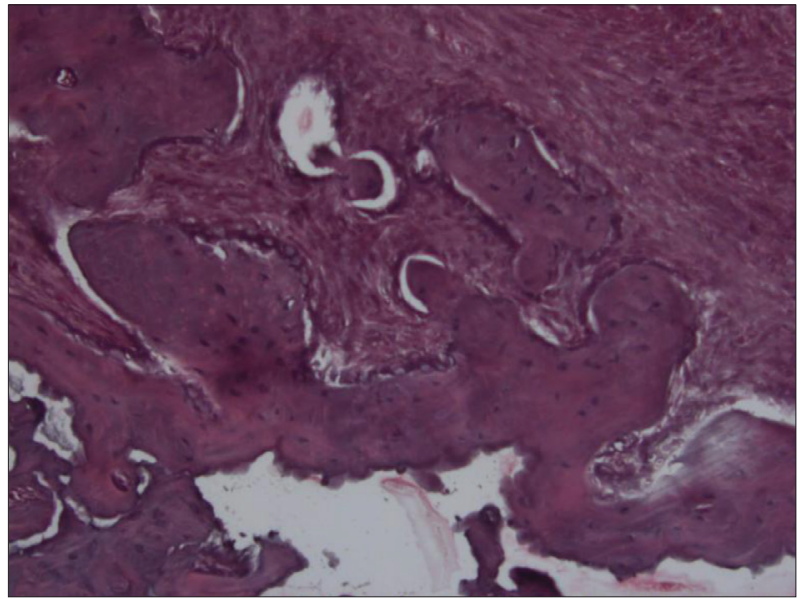

Figure 5. Histological finding of the defect after 30 days (no implantation of material- control group). Fibrovascular connective tissue surrounding newly formed bone can be seen (HE, 400x).

Slika 5. Histološki nalaz defekta kosti nakon 30 dana (kontrolna grupa). Fibrovaskularno vezivno tkivo okružuje ostrvca novoizgrađene kosti $(\mathrm{HE}, 400 \times)$.

placed in oval contours. Border cement lines were basophilic, enlarged, with amorphous to fine-grained appearance. In one case ( 1 of 6 ) giant cell reaction to a foreign body was observed.

Ninety days after material implantation, osteoplasia and trabeculae of different widths surrounded by osteoblasts were observed. Newly formed bone was young and morphologically immature. There was no restitutio ad integrum, but focal remodeling of bone tissue was intense (Figure 3). Fibrous connective tissue was focally distributed and reduced (in all samples). Bone tissue, away from experimental area showed normal morphology (Figure 4).

\section{Control group}

Thirtieth day after preparation of experimental defect in all control samples, osteosynthesis activity and fibrovascular connective tissue were observed (Figure 5). Young bone tissue with osteocytes in enlarged oval lacunae was noted. Thickened edges of osteons with increased basophil responses were present away from the experimental defect. No signs of inflammation in tissue were noted.

Ninety days after preparation of artificial defect, an ad integrum bone healing was noted in all samples of the control group. Osteons of newly formed bone tissue had smaller diameter and smaller number of concentric lamellae (Figure 6).

\section{DISCUSSION}

Before introducing any material in the clinical practice it is necessary to conduct appropriate tests. Cytotoxicity testing of endodontic materials by in vitro tests provides control of the experiment conditions but does not correspond completely to clinical situation. For this reason, implantation of materials (subcutaneous, intramuscular,

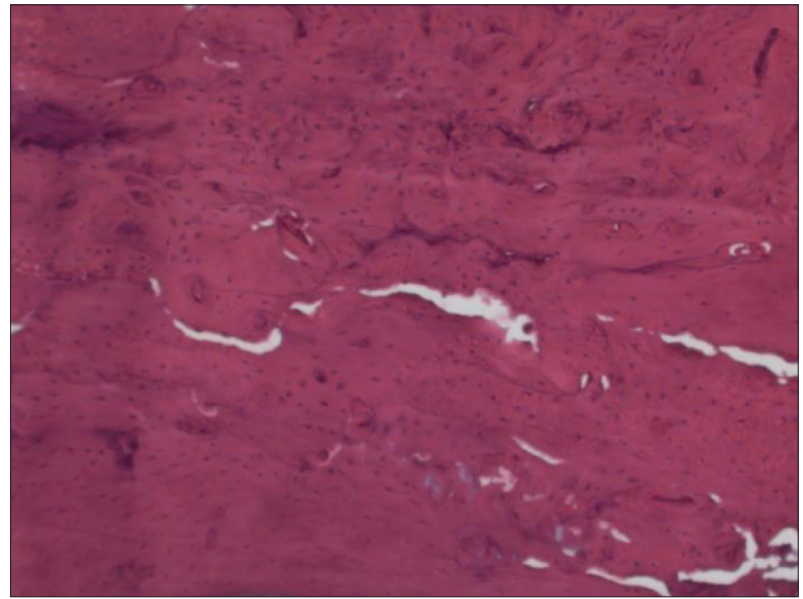

Figure 6. Histological finding of the defect after 90 days (no implantation of material-control group). Newly formed bone with osteon- type organization and borders to the lamellar bone are visible (HE, 200x).

Slika 6. Histološki nalaz defekta kosti nakon 90 dana (kontrolna grupa). Novostvorena kost sa organizacijom po tipu osteona i granica prema lamelarnoj kosti (HE, 200x).

intaoseal) is considered to be superior test. Tested materials are commonly implanted into the tissues of rats [5, $8,10]$, rabbits [11], guinea pigs [12]. Intraoseal models provide an adequate environment for in vivo testing of endodontic materials. In this experiment, the method of mandible bone implantation was chosen because of its specificity [13].

Eugenol (4-allyl-2-methoxyphenol) is clove oil extract and a component of zinc oxide eugenol ( $\mathrm{ZnOE})$. It causes periapical toxicity and inhibits growth and proliferation of human osteoblastic U2OS cell line. As cell growth, attachment, proliferation and synthesis of matrix play an important role in wound healing and tissue regeneration, it can be assumed that eugenol in tissue may disturb the processes of wound healing $[14,15]$.

Thirty days after the material (Endomethasone N) implantation, its presence was macroscopically observed inside the experimental defects. During the process of making histological preparations, the material was in most cases partially or completely rinsed from the implantation site and experimental defects were represented as empty spaces. After the experimental period of 90 days, microscopic analysis did not show tested material (Endomethasone N) present.

Thirtieth day after implantation of Endomethasone $\mathrm{N}$, fibrovascular connective tissue by type of callus was observed as well as new bone formation. Inflammatory response, in all samples, was slightly pronounced except in one case where the response was more type of reaction to the foreign body with granulation tissue. On the ninetieth day the absence of inflammatory reactions was recorded and slower degree of fibrovascular proliferation in relation to the period of 30 days. Connective tissue was mostly replaced with young bone tissue with osteon type structure.

In the control group after the period of 30 days an inflammatory reaction was observed which disappeared until the ninetieth day. Also, in the control group, the presence of connective tissue in the second period (90 
days) was not observed, and the experimental defect was completely replaced by newly formed bone tissue. The presence of connective tissue in the experimental group after 30 days and its reduction after 90 days suggest that after longer time it may be completely replaced by newly formed bone.

Results of the current study were similar to other studies $[13,14]$. Tassery et al. describe mild to moderate infiltration of inflammatory cells after 4 weeks when material Super EBA (based on zinc oxide) was implanted in the mandible of guinea pigs. This reaction decreased over time and it was not observed after 12 weeks. This study did not find healing disruption due to increased inflammatory reaction [13]. The initial inflammatory effect was attributed to eugenol and etoxybenzoic acid (Super EBA ingredient) that were released [16], but the setting of the material reduced their amount [17]. High degree of binding of these substances to serum and extracellular proteins may contribute to reduced toxicity and mild inflammation [18].

Triches et al. examined inflammatory reaction of subcutaneous tissue in rats using histomorphological parameters such as - quantity of inflammatory cells, presence of blood vessels, area of necrosis and the thickness of fibrous capsule. A mild to moderate tissue reaction to Endomethasone $\mathrm{N}$ was described after 7 days with predominance of chronic inflammatory cells, while after 42 days tissue remained inflamed with the presence of lymphocytes, fibroblasts and well-organized collagen fibres [14]. The authors came to the conclusion that all tested sealers (Endomethasone N, Endofil (based on $\mathrm{ZnO}$ ), Sealer 26 (based on $\left.\mathrm{CaOH}_{2}\right)$ ) were irritants; which toxicity was reduced over time.

Our study showed that after longer periods of time Endomethasone $\mathrm{N}$ slowed down the process of reparation and caused late inflammatory reaction which is consistent with the results of other authors [14, 19, 20]. In the study conducted by Suzuki \& Souza, Endomethasone did not provide complete healing even after 90 days. The experiment was carried out on dogs whose root canals were overfilled with this material, and then periradicular tissue was analyzed histologically. Occasionally inflammatory cell infiltrate of different degree was found in all samples, while giant cells were present in eight out of ten samples [20]. Our results also showed chronic weak inflammatory response of bone tissue to Endomethasone in the period after 30 days. That is consistent with another study that found mild inflammation in bone with signs of recovery after 42 days of subcutaneous implantation of Endomethasone in rats [14].

Ninetieth day after the implantation no signs of inflammation were noted and regenerative processes had prevalence in our study. These results do not agree with the findings of chronic inflammatory infiltrate even after the period longer than 90 days (six months) for overfilled root canals with Endomethasone in monkeys [19]. The results were explained by irritation that material caused when it was extruded beyond the apex. Discrepancies can be attributed to the variety of animal models and experimental design.
Other authors reported different results from ours. Zafalon et al. found moderate to severe inflammatory reaction after 15 days of implantation, while after 30, 60, 90 days, there was no reaction [10]. The time period was the same so the difference can be attributed to the experimental procedure and the difference in material composition of Endomethasone and Endomethasone-N.

The most ingredients of Endomethasone are released during setting reaction due to its high solubility [21]. Sealer components diffuse easier in the freshly mixed state, although they could be released by hydrolysis even after material is set [15]. Continuous release of toxic components such as paraformaldehyde and eugenol may explain persistent inflammation over longer period of time.

\section{CONCLUSION}

Endomethasone N slows down bone tissue healing process by showing the signs of prolonged inflammation in bone tissue in which it was implanted. Prolonged healing is reflected in slow replacement of fibrovascular connective tissue with newly formed bone tissue. However, permanent disturbance of morphofunctional relations in the bone tissue was not found.

\section{REFERENCES}

1. Vujašković M, Bacetić D. Reakcija tkiva na materijale za trajno punjenje kanala korena zuba Tissue Toxicity of Root Canal Sealers. Serbian Dent J. 2004; 51:136-41. [DOI: 10.2298/SGS0403136V]

2. Van Noort R. Introducing to dental materials. 3nd Edition. Edinburgh: Mosby; 2007. p. 272-8.

3. Bratel J, Jontell $M$, Dahlgren $U$, Bergenholt $G$. Effects of root canal sealers on immunocompetent cells in vitro and in vivo. Int Endod ). 1998; 31(3):178-88. [DOI: 10.1046/j.1365-2591.1998.00148] [PMID: 10321164]

4. L Gluskin $\mathrm{AH}$. Anatomy of an overfill: a reflection on the process. Endod Topics. 2007; 16:64-81. [DOI: 10.1111/j.16011546.2009.00238.x]

5. Zmener O, Guglielmotti MB, Cabrini RL. Biocompatibility of two calcium hydroxide-based endodontic sealers: a quantitative study in the subcutaneous connective tissue of the rat. J Endod. 1988; 14(5):229-35. [DOI: 10.1016/S0099-2399(88)80175-4] [PMID: 3075231]

6. Hauman CHJ, Love RM. Biocompatibility of dental materials used in contemporary endodontic therapy: A review. Part 2. Root-canal-filling materials. Int Endod J. 2003; 36(3):147-60. [DOl: 10.1046/j.1365-2591.2003.00637.x] [PMID: 12657140]

7. Geurtsen W. Biocompatibility of root canal filling materials. Aust Endod J. 2001; 27(1):12-21. [DOI: 10.1016/S1079-2104(98)90297-9] [PMID: 11481874]

8. Ogasawara T, Yoshimine Y, Yamamoto M, Akamine A. Biocompatibility of an experimental glass-ionomer cement sealer in rat mandibular bone. Oral Surg Oral Med Oral Pathol Oral Radiol Endod. 2003; 96:458-65. [DOI: 10.1016/S1079-2104(03)00060-X] [PMID: 14561972]

9. Pitt Ford TR. Tissue reactions to two root canal sealers containing formaldehyde. Oral Surg Oral Med Oral Pathol. 1985; 60(6):661-5. [DOI: 10.1016/0030-4220(85)90372-X] [PMID: 3865140]

10. Zafalon EJ, Versiani MA, de Souza C), Moura CC, Dechichi P. In vivo comparison of the biocompatibility of two root canal sealers implanted into the subcutaneous connective tissue of rats. Oral Surgery Oral Med Oral Pathol Oral Radiol Endodontology. 
2007; 103(5):88-94. [DOI: 10.1016/..tripleo.2006.11.025] [PMID: 17320427]

11. Pertot W, Camps J, Ramusat M, Proust J. In vivo comparison of the biocompatibility of two endodontic sealers implanted into the mandibular bone of rabbits. Oral Surg Oral Med Oral Pathol. 1992; 73:613-20. [DOI: 10.1016/0030-4220(92)90109-4] [PMID: 1518651]

12. Pissiotis E, Spângberg L. Reaction of bony tissue to implanted silver glass ionomer and a reinforced zinc oxide-eugenol cement. Oral Surg Oral Med Oral Pathol Oral Radiol Endod. 2000; 89(5):623-9. [DOl: 10.1067/moe.2000.105173] [PMID: 10807722]

13. Tassery H, Remusat M, Koubi G, Pertot WJ. Comparison of the intraosseous biocompatibility of Vitremer and Super EBA by implantation into the mandible of rabbits. Oral Surgery Oral Med Oral Pathol Oral Radiol Endod. 1997; 83(5):602-8. [DOI: 10.1016/ S1079-2104(97)90127-X] [PMID: 9159822]

14. Trichês KM, Júnior JS, Calixto JB, Machado R, Rosa TP, Silva EJ, et al. Connective tissue reaction of rats to a new zinc-oxide-eugenol endodontic sealer. Microsc Res Tech. 2013; 76(12):1292-6. [DOI: 10.1002/jemt.22299] [PMID: 24123537]

15. Ho YC, Huang FM, Chang YC. Mechanisms of cytotoxicity of eugenol in human osteoblastic cells in vitro. Int Endod J. 2006; 39(5):389-93. [DOI: 10.1111/j.1365-2591.2006.01091.x] [PMID: 16640638]
16. Hume W. The pharmacologic and toxicological properties of zinc oxide-eugenol. J Am Dent Assoc. 1986; 113(5):789-91. [DOl: 10.14219/jada.archive.1986.0256] [PMID: 3537057]

17. Hume WR. An analysis of the release and the diffusion through dentin of eugenol from zinc oxide-eugenol mixtures. I Dent Res. 1984; 63(6):881-4. [DOI: 10.1177/00220345840630061301] [PMID: 6588071]

18. Fujisawa S, Masuhara E. Binding of eugenol and o-ethoxybenzoic acid to bovine serum albumin. J Dent Res. 1981; 60(4):860-4. [DOI: 10.1177/00220345810600041801] [PMID: 6937526]

19. Bernáth $M$, Szabó J. Tissue reaction initiated by different sealers. Int Endod J. 2003; 36:256-61. [DOI: 10.1046/j.1365-2591.2003.00662.x] [PMID: 12702119]

20. Suzuki P, Souza V De, Holland R et al. Tissue reaction to Endométhasone sealer in root canal fillings short of or beyond the apical foramen. J Appl Oral Sci. 2011; 19(5):511-6. [DOI: 10.1590/S167877572011000500013]

21. Schwarze T, Fiedler I, Leyhausen G, Geurtsen W. The cellular compatibility of five endodontic sealers during the setting period. J Endod. 2002; 28(11):784-6. [DOI: 10.1097/00004770-20021100000009] [PMID: 12470025]

Received: 19.07.2016 • Accepted: 01.11.2016 


\title{
Uticaj materijala za opturaciju na bazi cink-oksida na zarastanje koštanih defekata
}

\author{
Marija Nikolić, Jelena Popović, Jovanka Gašić, Radomir Barac \\ Univerzitet u Nišu, Medicinski fakultet, Odeljenje za bolesti zuba i endodonciju, Klinika za stomatologiju, Niš, Srbija
}

\begin{abstract}
KRATAK SADRŽAJ
Uvod Cilj opturacije kao završne faze endodontskog tretmana je da se obezbedi kompletno hermetično zatvaranje duž cele dužine kanala od koronarnog otvora da apeksne granice.

Cilj studije bio je da se proveri histološki odgovor koštanog tkiva na implantaciju materijala na bazi cink-oksida u arteficijalno preparisan defekt u mandibuli pacova.

Metode rada $U$ eksperimentu je upotrebljeno 16 pacova Wistar soja, muškog pola. Upotrebom sterilnih, čeličnih fisurnih borera formiran je defekt između medijalne linije i mentalnog otvora u mandibuli pacova. Siler baziran na cink-oksidu je implantiran u defekte eksperimentalne grupe, dok su defekti kod kontrolne grupe ostavljeni da spontano zarastaju. Polovina životinja iz obe grupe je žrtvovana posle trideset, a druga polovina posle devedeset dana. Mikroskopski preparati su se sastojali od defekta i okolne kosti i posle pripreme su analizirani svetlosnom mikroskopijom.

Rezultati Trideset dana posle implantacije je uočeno fibrovaskularno vezivno tkivo sa oskudnim hroničnim inflamatornim infiltratom. Dalje od eksperimentalnog defekta, u dubini kosti, zapažena je lamelarna kost sa dobro formiranim većim osteonima i proširenim Haversovim i Folkmanovim kanalima. Devedeset dana posle implantacije materijala nije došlo do restitutio ad integrum, ali je fokalno remodelovanje kosti bilo intenzivno.

Zaključak Endometazon N usporava proces zarastanja koštanog tkiva jer pokazuje znake produženog zapaljenja u koštanom tkivu u koje je implantiran. Produženje procesa zarastanja ogleda se i u usporenoj zameni fibrovaskularnog vezivnog tkiva novonastalim koštanim tkivom.

Ključne reči: sileri; opturacija; zarastanje kosti
\end{abstract}

\section{UVOD}

Opturacija kao završna faza endodontskog tretmana ima za cilj obezbeđivanje kompletnog hermetičnog punjenja duž celokupne dužine kanalskog sistema od koronarnog otvora do apeksne granice. Uloga opturacije je da se spreči komunikacija između endodonta i parodonta i na taj način onemogući reinfekcija periapeksne regije [1]. Materijali koji se upotrebljavaju bi trebalo da poseduju niz fizičkih, hemijskih i bioloških osobina i po pravilu ne bi trebalo da se prostiru izvan granica kanalskog sistema [1]. Kada biomaterijal dođe u kontakt sa tkivima i tečnostima ljudskog organizma, uvek postoji neka forma interakcije i zato je potrebno da materijal bude biokompatibilan, neškodljiv u biološkoj sredini, a da je pacijent zaštićen od bilo kakvih negativnih uticaja [2].

Preterana instrumentacija i sledstveno prepunjavanje kanala korena značajno povećavaju rizik od nepovoljnog uticaja materijala za punjenje [3]. Prepunjavanje utiče na povećanu inflamaciju i usporeno zarastanje $[4,5]$. Negativno dejstvo je obično izraženije dok materijal još nije potpuno vezan i uglavnom se pripisuje sastavnim komponentama materijala [6]. Sporo oslobađanje negativnih agenasa tokom dužih perioda vremena zavisi od rastvorljivosti materijala, odnosno stepena izloženosti materijala tkivnim tečnostima [2].

Materijali na bazi cink-oksida sa eugenolom su najčešće upotrebljavani i obično se koriste kao komparativni sileri u studijama koje ispituju biološke efekte materijala [4, 7]. Rezultati ovih studija, međutim, nisu ohrabrujući. S obzirom na to da su prema nekim autorima pojedini materijali iz ove grupe veoma toksični, oni ih ne preporučuju za upotrebu [7]. Toksičnost se uglavnom pripisuje prisustvu eugenola ili formaldehida, koji neki od ovih materijala sadrže $[8,9]$.

\section{CILJ RADA}

Cilj istraživanja bio je da se proveri histološki odgovor koštanog tkiva na implantaciju materijala na bazi cink-oksida u arteficijalno preparisan defekt u mandibuli pacova.

\section{METOD RADA}

U eksperimentu je korišćeno 16 Wistar pacova muškog pola, telesne mase 160-180 g (odobreno od strane Etičkog komiteta Medicinskog fakulteta u Nišu, broj 01 3797). Tokom eksperimentne procedure životinje su anestezirane intraperitonealnom injekcijom ketamin-hidrohlorida $(0,1 \mathrm{ml}$ na $100 \mathrm{ml}$ telesne mase). Nakon postupka pripreme, između središnje linije i mentalnog otvora sa leve strane donje vilice svih životinja, napravljen je defekt (prečnika 1,4 mm i dubine 1,6 mm) korišćenjem sterilnog fisurnog čeličnog borera. Životinje eksperimentalne grupe podeljene su u dve podgrupe:

- Prva podgrupa $(\mathrm{n}=6)$ žrtvovana nakon 30 dana

- Druga podgrupa $(n=6)$ žrtvovana nakon 90 dana

U formirane defekte kod eksperimentalne grupe životinja implantiran je endometazon N (Septodont, France) pripremljen po uputstvu proizvođača. Preparisan defekt kod životinja kontrolne grupe $(n=4)$ ostavljen je da spontano zarasta bez ikakvog implantata. Dve životinje iz kontrolne grupe su žrtvovane posle 30, a dve posle 90 dana. Nakon predviđenog vremena životinje su žrtvovane predoziranjem anestetikom (ketaminhidrohlorid). Uzorci tkiva su napravljeni resekcijom mandibule, a sastojali su se od defekta i okolne kosti. Uzorci tkiva su fiksirani u $10 \%$ puferisanom formalinu, demineralizovani u $10 \%$ mravljoj kiselini, dehidrirani u seriji alkohola, a zatim kalupljeni u parafinskom vosku. Sečenje je izvedeno u bukolingvalnom 
pravcu na mikrotomu staklenim noževima $2 \mu \mathrm{m}$ debljine. Preparati su bojeni hematoksilin-eozin metodom i mikroskopski analizirani svetlosnim mikroskopom VH50 (Olimpys, Japan) opremljenim digitalnom kamerom Leica DFC 295.

\section{REZULTATI}

\section{Eksperimentalna grupa}

Tridesetog dana posle implantacije materijala uočava se fibrovaskularno vezivno tkivo, sa oskudnim hroničnim inflamativnim ćelijskim infiltratom u vidu fokusa, dok je okolna kost hipocelularna i bez prisustva Haversovih sistema (kod pet od šest uzoraka) (Slika 1). Osteociti malih hiperhromatičnih jedara su smešteni u lako proširene lakune. Osteoblasti su malobrojni, dok je prisustvo osteoklasta neupadljivo. Na mestima neresorbovanog materijala, ispalog tokom obrade histopatoloških preparata, zapažaju se prazni prostori. Dalje od eksperimentalno načinjenog defekta, prema dubini kosti, uočava se lamelarna kost sa dobro formiranim većim osteonima, proširenih Haversovih i Folkmanovih kanala (Slika 2). U osteonima se zapažaju proširene intersticijalne lamele, a osteociti su smešteni u lakune ovalnih kontura. Granične cementne linije su bazofilne, proširene, sitnozrnastog do amorfnog izgleda. U jednom slučaju (jedan od šest) uočena je džinovsko-ćelijska reakcija na strano telo.

Devedeset dana nakon implantacije materijala u preparisan defekt u koštanom tkivu se zapaža osteoplazija i formiranje trabekula različite širine, koje su okružene osteoblastima. Novoformirana kost je mlada, morfološki nezrela. Nije došlo do restitutio ad integrum, ali je fokalno remodelovanje koštanog tkiva intenzivno (Slika 3). Fibrozno vezivno tkivo je fokalno raspoređeno i redukovano (kod svih uzoraka). Koštano tkivo dalje od eksperimentalnog područja pokazuje normalnu morfologiju (Slika 4).

\section{Kontrolna grupa}

Tridesetog dana od preparacije eksperimentalnog defekta kod svih uzoraka kontrolne grupe zapaža se osteosintetska aktivnost i fibrovaskularno vezivno tkivo (Slika 5). Prisutno je mlado koštano tkivo čiji osteociti imaju proširene ovalne lakune. Dalje od eksperimentalnog defekta se uočavaju zadebljali rubovi osteona pojačano bazofilne reakcije (Slika 6). U tkivu nema znakova zapaljenja.

Devedeset dana od preparacije arteficijalnog defekta kod kontrolne grupe (svi uzorci) uočava se potpuno zarastanje ad integrum. Osteoni novonastalog koštanog tkiva pokazuju manji dijametar i manji broj koncentričnih lamela (Slika 6).

\section{DISKUSIJA}

Pre preporuke za kliničku upotrebu nekog materijala neophodno je sprovesti odgovarajuće testove. Testiranje citotoksičnosti endodontskih materijala in vitro testovima omogućava kontrolisanje uslova eksperimenta, ali ne odgovara u dovoljnoj meri kliničkoj situaciji. Iz tog razloga se tehnike implantacije (subkutane, intramuskularne, intraosealne) smatraju superiornijim. Materijali koji se testiraju implantiraju se u tkiva pacova $[5,8$,
10], zečeva [11], zamoraca [12]. Intraosealni modeli obezbeđuju adekvatno okruženje za in vivo testiranje endodontskih materijala. U ovom eksperimentu je korišćena metoda koštane implantacije, a odabrana je mandibula zbog specifičnosti svoje građe [13].

Eugenol (4 alil-2-metoksifenol) jeste ekstrakt ulja karanfilića i predstavlja sastojak cinkoksid-eugenola $(\mathrm{ZnOE})$. Izaziva periapeksnu toksičnost i inhibiše rast i proliferaciju U2OS humane osteoblasne ćelijske linije. S obzirom na to da ćelijski rast, vezivanje, proliferacija i sinteza matriksa igraju važnu ulogu u zarastanju rana i tkivnoj regeneraciji, može se pretpostaviti da oslobođeni eugenol može uzrokovati poremećaje u zarastanju [14, 15].

U eksperimentalnom periodu od 30 dana unutar eksperimentalnih defekata makroskopski je zapaženo prisustvo ili manji ostaci materijala (endometazon N). Tokom tehnike obrade uzorkovane kosti i izrade histoloških preparata opturacioni materijal je u najvećem broju slučajeva potpuno ili delimično ispao sa mesta implantacije, a eksperimentalni defekti svetlosno-mikroskopski su bili predstavljeni kao prazni prostori. U eksperimentalnom periodu od 90 dana makroskopski i svetlosno-mikroskopski primenjeni opturacioni materijal (endometazon N) nije uočen.

Tridesetog dana od implantacije materijala endometazona $\mathrm{N}$ uočeni su fibrovaskularno vezivno tkivo po tipu kalusa i stvaranje nove kosti. Inflamativni odgovor je kod svih uzoraka bio blago izražen osim u jednom slučaju gde je uočen odgovor po tipu reakcije na strano telo sa granulacionim tkivom i okolnom reaktivno izmenjenom kosti. Devedesetog dana zabeleženi su odsustvo inflamativne reakcije u tkivu i manji stepen fibrovaskularne proliferacije u odnosu na period od 30 dana. Vezivno tkivo je najvećim delom zamenjeno mladim koštanim tkivom sa građom po tipu osteona.

U eksperimentalnoj grupi u ovom istraživanju je u ranijem periodu (30 dana) uočena zapaljenska reakcija, koja se do devedesetog dana potpuno povukla. Takođe, kod kontrolne grupe, za razliku od eksperimentalne, nije uočeno prisustvo vezivnog tkiva u drugom vremenskom periodu (90 dana), već je eksperimentalni defekt potpuno zamenjen novonastalim koštanim tkivom. Prisustvo vezivnog tkiva kod eksperimentalne grupe nije bilo izraženo i primećeni su znaci njegovog smanjivanja u odnosu na raniji period, pa bi se moglo pretpostaviti da će s vremenom potpuno biti zamenjeno novostvorenom kosti.

Reakcija tkiva slična dobijenoj u ovoj studiji sreće se i u istraživanjima drugih autora $[13,14]$. Kod implantacije materijala Super EBA (na bazi cink-oksida) u mandibule zamoraca, Tassery i sar. opisuju blagu do umerenu infiltraciju inflamativnim ćelijama posle četiri nedelje. Ova reakcija se smanjivala vremenom i nije zapažena posle 12. nedelje. Pomenuto istraživanje ne ukazuje na ometanje zarastanja niti na pojačanu reakciju inflamacije [13]. Inicijalni inflamativni efekat se pripisuje eugenolu i etoksibenzoevoj kiselini (sastojak Super EBA), koji se oslobađaju [16] i čije se otpuštanje smanjuje sa vezivanjem materijala [17]. Visok stepen vezivanja ovih supstanci za serum i ekstracelularne proteine može doprineti redukovanoj toksičnosti i pratećoj blagoj inflamaciji [18].

Inflamativna reakcija subkutanog tkiva pacova je dobijena i u studiji Triches i sar., gde su ispitivani histomorfološki parametri kao što su kvantitet inflamativnih ćelija, prisustvo krvnih sudova, zona nekroze i debljina fibrozne kapsule. Opisana je blaga do umerena tkivna reakcija na endometazon $\mathrm{N}$ posle 
sedam dana sa predominacijom hroničnih inflamativnih ćelija, dok je 42. dana tkivo ostalo blago inflamirano, sa prisustvom limfocita, fibroblasta i dobro organizovanih kolagenih vlakana [14]. Autori su došli do zaključka da su svi testirani sileri (endometazon N, endofil (na bazi $\mathrm{ZnO}$ ), Sealer 26 (na bazi $\mathrm{CaOH}_{2}$ )) iritansi, čija se toksičnost vremenom smanjuje.

Kada su u pitanju dugi vremenski periodi, rezultati dobijeni u ovoj studiji su saglasni sa rezultatima drugih autora koji potvrđuju da endometazon $\mathrm{N}$ usporava procese reparacije i izaziva kasnu zapaljensku reakciju $[14,19,20]$.

U istraživanju koje su sproveli Suzuki \& Souza, kod endometazona nije zapaženo idealno zarastanje ni posle 90 dana. Eksperiment je sproveden na psima čiji su kanali korena zuba prepunjavani ovim materijalom, a zatim patohistološki analizirana reakcija periradiksnog tkiva. Hronični zapaljenski ćelijski infiltrat različitog stepena javio se kod svih uzoraka, dok su gigantske ćelije bile prisutne kod osam od deset uzoraka [20].

Dobijeni rezultati u ovoj studiji takođe ukazuju na hroničnu inflamativnu reakciju koštanog tkiva na endometazon u periodu posle 30 dana, koja je slabog intenziteta, što je u saglasnosti sa autorima koji ukazuju na blagu inflamaciju sa znacima regeneracije posle 42. dana od subkutane implantacije endometazona kod pacova [14].

Devedesetog dana od implantacije nisu uočeni znaci zapaljenja, već preovladavanje regenerativnih procesa. Ovi se rezultati ne slažu sa nalazima autora koji hronični zapaljenski infiltrat registruju i posle perioda dužih od 90 dana (šest meseci) kod prepunjenih kanala endometazonom kod majmuna [19]. Dobijene rezultate objašnjavaju iritacijom koju materijal izaziva kada se prebaci preko apeksa korena zuba. Neslaganje rezultata može se pripisati različitim životinjskim modelima i eksperimentalnom dizajnu.

Podaci iz literature, kod ispitivanja endometazona in vivo subkutanim testom ukazuju na rezultate različite od dobijenih u ovoj studiji. Zafalon i sar. su ustanovili umerenu do jaku inflamativnu reakciju nakon 15 dana od implantacije, a posle 30 , 60,90 dana reakcije nije bilo [10]. S obzirom na to da se radi o istom vremenskom periodu, razlike se mogu pripisati eksperimentalnoj proceduri i razlici u sastavu materijala endometazona i endometazona $\mathrm{N}$.

Najviše sastojaka endometazon oslobađa tokom reakcije vezivanja, što se može objasniti velikom rastvorljivošću materijala [21]. Komponente silera lakše difunduju u sveže zamešanom stanju, iako se eugenol može osloboditi hidrolizom i iz vezanog materijala [15]. Kontinuirano ispuštanje toksičnih komponenata poput eugenola i paraformaldehida može objasniti perzistiranje inflamacije tokom dužeg vremenskog perioda.

\section{ZAKLJUČAK}

Na osnovu dobijenih rezultata može se zaključiti da endometazon $\mathrm{N}$ usporava proces zarastanja koštanog tkiva jer pokazuje znake produženog zapaljenja u koštanom tkivu u koje je implantiran. Produženje procesa zarastanja ogleda se i u usporenoj zameni fibrovaskularnog vezivnog tkiva novonastalim koštanim tkivom, ali materijal ne dovodi do trajnog narušavanja morfofunkcionalnih odnosa u tkivu. 